\section{Imaging hallmark of Xpl1.2 translocation renal cell carcinoma}

\author{
Binit Sureka, MD, DNB, MBA, MNAMS, DHA; \\ Kalpana Bansal, MD; \\ Ankur Arora, MD, FRCR, DNB, EDiR
}

Department of Radiology, Institute of Liver \& Biliary Sciences, New Delhi, India

Cite as: Can Urol Assoc J 2015;9(7-8):E572. http://dx.doi.org/10.5489/cuaj.2817 Published online August 10, 2015.

W e read with great interest the recent case report on $\mathrm{Xp} 11.2$ translocation renal cell carcinoma (RCC) by Taşkınlar and colleagues. ${ }^{1}$ The authors have highlighted a very interesting case of complicated renal Bosniak IV cyst which turned out to be Xp11.2 translocation RCC. We wish to supplement few important computed tomographic (CT) imaging features which can predict this morphological subtype of RCC.

The World Health Organization has classified RCC associated with Xp11.2 translocation and TFE3 gene fusion (Xp11RCC) as a separate entity. ${ }^{2}$ Both Xp11.2 translocation RCC and papillary RCC are hypovascular tumours and can be solid, mixed solid and cystic, and predominantly cystic. Recently, Woo and colleagues, ${ }^{3}$ in their 19 histopathologically cases of Xp11 RCC, found pointers for differentiating Xp11 RCC from papillary RCC: presentation in children and young adults, female gender, larger tumour size, cystic and
CUAJ Letters is an open forum to discuss papers published in CUAJ. Letters are published at the discretion of the editors, and are subject to abridgement and editing for style and content. Letters can be sent to the Editor at journal@cua.org. necrotic changes, calcification, high-attenuating areas than the renal cortex on non-contrast scans, aggressive behaviour of lymph node, and distant metastasis.

We hope that supplementing these imaging features will help urologists and their fellow radiologists and pathologists (appropriate immunohistochemical staining) in making preoperative diagnosis of this rare renal tumour.

Competing interests: The authors all declare no competing financial or personal interests.

This paper has been peer-reviewed.

\section{References}

1. Taşkınlar H, Avlan D, C,itak C, et al. A rare cause of childhood renal cysts: Xp 11.2 translocation renal cell carcinoma. Can Urol Assoc J 2015;9:E36-8. http://dx.doi.org/10.5489/cuai.2321

2. Lopez-Beltran A, Scarpelli M, Montironi R, et al. 2004 WHO classification of the renal tumors of the adults. Eur Urol 2006;49:798-5. hrtp://dx.doi.org/10.1016/i.eururo.2005.11.035

3. Woo S, Kim SY, Lee MS, et al. MDCT findings of renal cell carcinoma associated with Xp11.2 translocation and TFE3 gene fusion and papillary renal cell carcinoma. AJR Am J Roentgenol 2015;204:542-9. http:// dx.doi.org/10.2214/AJR.14.12950

Correspondence: Dr. Binit Sureka, Department of Radiology, Institute of Liver \& Biliary Sciences, New Delhi-1 10070; binitsurekapgi@gmail.com 